\title{
Intra-puparial development of Lucilia eximia (Diptera, Calliphoridae)
}

\author{
Yardany RAMOS-PASTRANA ${ }^{1,2 *}$, Carlos Andres LONDONON ${ }^{1}$, Marta WOLFF $^{2}$ \\ 1 Universidad de la Amazonia, Laboratorio de la Entomología, Grupo -GAIA-, Grupo de Investigación en Agroecosistemas y Conservación en Bosques Amazónicos. Florencia, \\ Caquetá, Colombia. \\ ${ }^{2}$ Universidad de Antioquia, Grupo de Entomología GEUA. Medellín, Colombia. \\ * Corresponding author: ya.ramos@udla.edu.co
}

\section{ABSTRACT}

There are few studies about the intra-puparial development in Diptera, nonetheless its importance has been increased because several dipteran species are of forensic interest. Studies on the life cycles of flies often disregard the changes that occur inside the pupae. The objectives of this research were to analyze the intra-puparial development of Lucilia eximia, and to describe chronological and morphological changes that occur during this stage. Around 1.600 specimens were laboratory-reared. The pre-pupae were identified by the reduction of their size and change in coloration, and 10 individuals were sampled every three hours ( $\mathrm{n}=1.000)$ until adult emergence. The specimens were fixed in $96 \%$ alcohol, subsequently immersed in Canoy solution for 24 hours and in formic acid (5\%) for 48 hours, to facilitate dissection and analysis of the morphological changes of the individuals. Four stages of the intra-pupal development of $L$. eximia were observed: 1) Larva-pupa apolysis, which lasted $23 \pm$ 1.08 h; 2) Cryptocephalic pupa, $5 \pm 0.53$ h; 3) Phanerocephalic pupa, $92 \pm 1.94 \mathrm{~h}$; and 4) Pharate adult: Transparents eyes, $125 \pm 2.15 \mathrm{~h}$; Yellow eyes, $23 \pm 0.89 \mathrm{~h}$; Pink eyes, $14 \pm 0.73 \mathrm{~h}$; and Red eyes, $20 \pm 0.60 \mathrm{~h}$. The pharate adult is completely formed after 296 hours and the emergence of the adult occurred after $302 \pm 3.81 \mathrm{~h}$. In addition, there were included the stage of pre-pupa, pupariation and the beginning of the adult stage, Imago and adult emergence. Each stage is described and compared with those described for Chrysomya albiceps (Calliphoridae).

KEYWORDS: Immature insects, Metamorphosis, Forensic entomology, Postmortem interval.

\section{Desenvolvimento Intra-pupal de Lucilia eximia (Diptera: Calliphoridae)}

\begin{abstract}
RESUMO
No mundo existem poucos estudos sobre o desenvolvimento intrapupal de Diptera. Comumente, os estudos dos ciclos de vida das espécies de moscas são feitos eliminando o desenvolvimento embrionário que é muito importante, principalmente nas espécies de interesse forense. O principal objetivo foi o de analisar o desenvolvimento intrapupal de Lucilia eximia, descrevendo as mudanças morfológicas que ocorrem durante o desenvolvimento intrapupal. Foram analisados cerca de 1.600 espécimes cultivados em laboratório. Foram analisadas as fases de pré-pupa, pupa, o início da fase adulta, a imago e a emergência. Prépupas foram identificadas de acordo com a redução no tamanho e na alteração da coloraçáo. Dez espécimes foram coletados a cada três horas $(\mathrm{n}=1.000)$, sem interrupção, até a emergência dos adultos. As pupas foram fixadas em etanol a $96 \%$. Em seguida foram imersas em solução Carnoy por 24 horas e ácido fórmico a 5\% por 48 horas para facilitar a dissecação e análises das alteraçóes morfológicas. Foram determinados 4 estágios de desenvolvimento intrapupal. 1) Apólise larva-pupa com duração de $23 \pm 1,08$ h; 2) Pupa criptocefálica: $5 \pm 0,53$ h; 3) Pupa fanerocefálica: $92 \pm 1,94$ h e; 4) Adulto farado: olhos transparentes: $125 \pm 2,15$ h; olhos amarelos: $23 \pm 0,89$ h; olhos róseos: $14 \pm 0,73 \mathrm{~h}$ e olhos vermelhos $20 \pm 0,60 \mathrm{~h}$. O adulto farado estava completo após 296 horas e a emergência dos adultos ocorreu com $302 \pm 3,81 \mathrm{~h}$. Cada fase foi descrita e comparada com o descrito para Chrysomya albiceps (Calliphoridae).
\end{abstract}

PALAVRAS-CHAVE: Insetos imaturos, Metamorfose, Entomologia forense, Intervalo pós-morte. 


\section{INTRODUCTION}

The decomposition process begins soon after the death of an organism. When a corpse is exposed in the environment, it can be colonized by insects and other arthropods, mainly larvae of necrophagous Diptera (Amendt et al. 2004). The presence of an insect is often used as a tool for the postmortem interval estimation (PMI) (Disney and Manlove 2005; PujolLuz et al. 2008).

The age of the pupa has been used to estimate the postmortem interval, and has also been documented for a few dipteran species of forensic importance such as in the Calliphoridae: Calliphora erythrocephala (Macquart, 1834) (Wolfe 1954), Chrysomya albiceps (Wiedemann, 1819) (PujolLuz and Barros-Cordeiro 2012) and Chrysomya rufifacies (Macquart, 1842) (Ma et al. 2015)]; Muscidae: Musca domestica Linneaus, 1758 (Fraenkel and Bhaskaran 1973); Sarcophagidae: Sarcophaga bullata (Parker, 1916) (Fraenkel and Bhaskaran 1973); and Stratiomyidae: Hermetia illucens (Linnaeus, 1758) (Barros-Cordeiro et al. 2014). This information has also been reported for some dipterans with medical and veterinary interest: Cephenemya phobifera (Clark, 1815) (Bennett 1962), Cuterebra tenebrosa Coquillet, 1898 (Baird 1972; Baird 1975), Dermatobia hominis (Linnaeus Jr., 1781) (Lello et al. 1985), Hypoderma linaetum (Viller, 1789), Hypoderma bovis (Linnaeus, 1761) (Scholl and Weintraub 1988), Cuterebra fontinella Clark, 1827 (Scholl 1991), and Oestrus ovis (Linnaeus, 1758) (CepedaPalacios and Scholl 2000).

Lucilia eximia (Wiedemann, 1891) (Diptera: Calliphoridae) is associated with animal remains that decay in urban environments, mainly the ones exposed to sunlight (Barros-Souza et al. 2012; Archer and Elgar 2003). This species is considered of medical and veterinary importance and it has been used in forensic entomology as a biological indicator of PMI (Moura et al. 1997).

Lucilia eximia is a cosmopolitan fly (Whitworth 2014). In the neotropics this species is found from the north of Mexico to south South America (Whitworth 2014), and had also been reported in forensic studies in Europe (Velásquez et al. 2010), in North America (Debry et al. 2013; Sanford et al. 2014), in Central America (Garcés et al. 2004; Calderón-Arguedas et al. 2005), and in South America (Rocha et al. 2010; RamosPastrana and Wolff 2011; Barros-Souza et al. 2012; UrarahyRodrigues et al. 2013; Ramos-Pastrana et al. 2014). The objectives of this research were to analyze the intra-puparial development of Lucilia eximia, and to describe chronological and morphological changes that occur during this stage.

\section{MATERIALS AND METHODS}

This study was carried out at the Entomology Laboratory of the of the Universidad de la Amazonia, Florencia - Caquetá, Colombia.

About 1.600 mature larvae (L3) of $L$. eximia originated from the eggs laid by approximately 45 females specimens collected in the city of Florencia (Caquetá, Colombia) were reared and monitored into an incubation chamber (BOD) $\left(25.46 \pm 1.21^{\circ} \mathrm{C}, 93.31 \pm 2.41 \mathrm{RH}, 12: 12 \mathrm{~L}: \mathrm{D}\right)$ until they stopped feeding, became pink and began leaving the carcass. They were then placed into plastic containers with vermiculite from which 10 individuals were continuously sampled every three hours day-night $(\mathrm{n}=1000)$ until the emergence of adults. The sampled specimens were fixed in ethanol (96\%), followed first by a treatment with Carnoy solution for 24 hours and then with formic acid (5\%) for 48 hours. This chemical treatment, facilitated the removal of the puparium using the methodology proposed by Cepeda-Palacios and Scholl (2000), Pujol-Luz and Barros-Cordeiro (2012) and Barros-Cordeiro et al. (2014).

The pupae and adults obtained were killed with ethyl acetate in a killing jar. Some adults and all pupae were preserved in ethanol (96\%). The remaining specimens were pinned and then used to confirm their species with the keys proposed by Vargas and Wood (2010) and Whitworth (2014), and the morphology of the pupae was described. Finally, the specimens were deposited in the Entomological Collection of the Universidad de la Amazonia (CEUAM).

\section{Intra-puparial development}

To observe the development of the puparium and pupa, fixed puparia were dissected and the pupae extracted using a surgical scalpel under a binocular stereoscope (Leica EZ4, Leica Microsystems (Schweiz), Germany). All observations were documented and imaged using a photographic camera (Optika PRO 5 Digital Camera 4083.12, Italy) adapted to the stereoscope. In addition it is included the stage of pre-pupa, pupariation and the morphological description of the pupa and the beginning of the imago and emergence, according to Fraenkel and Bhaskaran (1973), Pujol-Luz and BarrosCordeiro (2012) and Barros-Cordeiro et al. (2014)

The methodology used in this study was adapted from Cepeda-Palacios and Scholl (2000) and Pujol-Luz and Barros-Cordeiro (2012). To describe the morphology of the intra-puparial stages we used the methodology of Fraenkel and Bhaskaran (1973), Cepeda-Palacios and Scholl (2000) and Pujol-Luz \& Barros-Cordeiro (2012).

This study was designed to analyze and describe the morphology of the intra-puparial development stages, because it is important to have the duration of each stage determined. To describe the period of time for each stage, the mean and 
the standard error were obtained using the software Estimates version 8.0 for Windows (Colwell 2006).

\section{RESULTS}

Intra-puparial development lasted $302 \pm 3.81$ hours, and four stages were observed: Larvae-pupa apolysis, Cryptocephalic pupa, Phanerocephalic pupa and Pharate adult.

\section{Pre-pupa}

Pre-pupa and Pupariation (lasted 80 hour). Before the pre-pupa stage the larvae stop feeding, became pink, and leave the carcass to find a substrate to pupate, being active for an additional period of six hours (Figure 1A). Subsequently, they buried into the substrate, and began the pre-pupae stage. In this stage the cephalic segment was retracted into the second segment, and the cephalopharyngeal skeleton remained immersed. The $12^{\text {th }}$ segment undergoes invagination into the $11^{\text {th }}$, and this process continues up to the invagination of the $8^{\text {th }}$ into the $7^{\text {th }}$ segment, giving it a barrel shape, and the intestine is emptied (Figures 1B, 1C). The length is reduced to $25.53 \%$ of its starting length, and lasted $80 \pm 1.5 \mathrm{~h}$ (Table 1).

\section{Morphological description of the pupa}

The pupa of Lucilia eximia posseses a typical coarctate form, between $6 \mathrm{~mm}$ long and $2.31 \mathrm{~mm}$ wide, with dark brown color. The fifth segment has a depression that marks the division of the head, and the mandible and maxilla are attached to the puparium. The top (ring 1) has a trapezoidal shape form (Figure 2A) and bears the anterior spiracles, with 6-8 buds each one (Figure 2B). The posterior ring has the spiracular plate, with two well pigmented spiracles, each one with three clefts, and a complete peritreme (Figure 2C).

\section{Stages of intra-puparial development}

Larva-pupa apolysis - The darkening and hardening of the puparium begins from the lateral zone towards the middle area of the dorsal region, and from the middle zone of the ventral region towards the ends (Figure 1D), and then extending to the dorsal area (Figure 1E). During the first six hours, the epidermis was still attached to the puparium, which made it difficult its release. This phase lasts $23 \pm 1.08 \mathrm{~h}$ (Table 1).

Cryptocephalic pupa (observed at 23 to $28 \mathrm{~h}$ ) - This stage is characterized by the secretion of the pupal skin and the complete separation of the epidermis from the puparium, which facilitates its extraction. Additionally, the head and the thoracic appendages are still invaginated (Figure 3A), the abdomen still has the aspect of the larva, and the head and thorax can not be differentiated in dorsal view (Figure 3B). All the structures of the cephalopharyngeal skeleton are found in the larva (Figures 3A and 3B), with the exception of the maxilla and mandible, which stay adhered to the puparium. This stage lasts $5 \pm 0.53 \mathrm{~h}$ (Table 1 ).
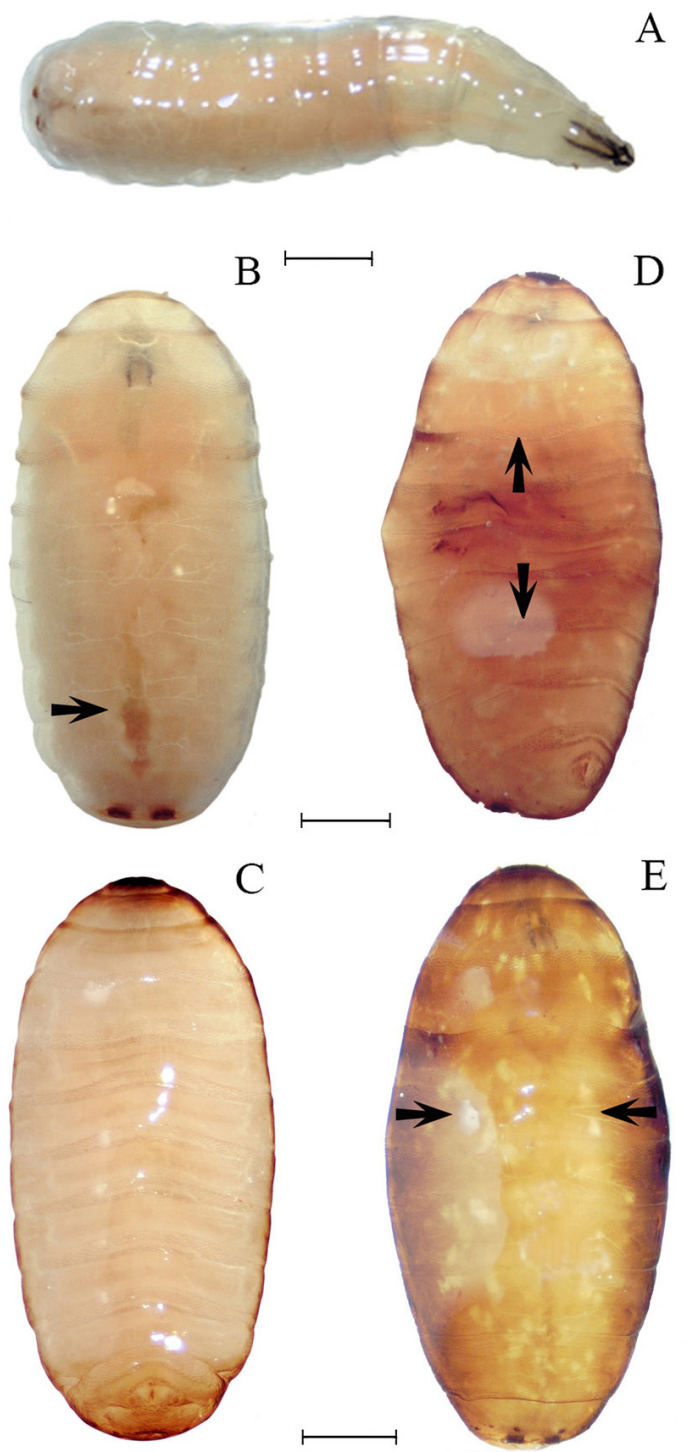

Figure 1. Morphological description of the pupariation process of Lucilia eximia. Post-feeding pink larva, in lateral view A. White puparium with empty intestine (arrow), in ventral view B. and dorsal view C. Larva pupa apolysis, darkening and hardening of the puparium (arrows) from the middle zone to the extremes, in ventral view D. Darkening and hardening of the puparium from the lateral zone of the dorsal region to the middle area (arrows), in dorsal view $\mathrm{E}$. This stage lasts $23 \pm 1.08 \mathrm{~h}$. PL: Pink Larvae. Scale bars: $1 \mathrm{~mm}$. This figure is in color in the electronic version.

Phanerocephalic pupa (observed at 28 to $120 \mathrm{~h}$ ) - This period is characterized by the complete extroversion of the cephalic capsule, however the thoracic appendages continue invaginated (Figure 3C). Segmentation is visible and it is possible to identify the abdominal sternites and tergites, as well as the prothoracic spiracles; however, the specimen still retains a pupa aspect (Figure 3D). This stage lasts $92 \pm 1.94 \mathrm{~h}$ (Table 1). 

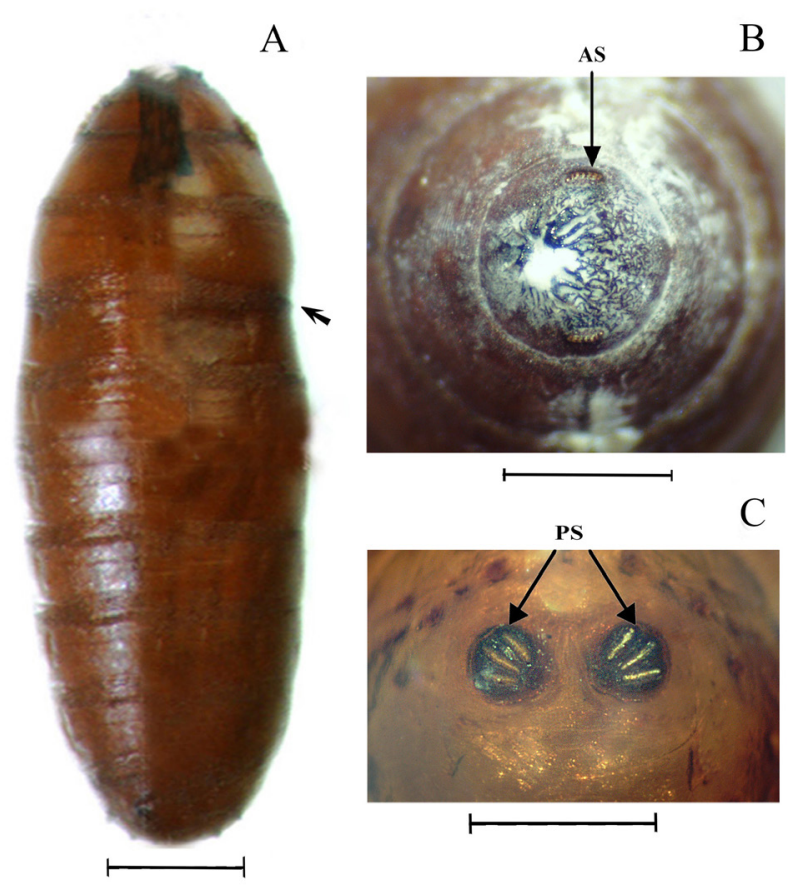

Figure 2. External morphology of the pupa of Lucilia eximia. Depression shows the division of the head (arrow) in a ventral view A. Anterior view of the ring two with anteriors spiracles B. View of the posterior ring with spiracular plate C. AS: Anterior Spiracles, PS: Posterior Spiracles. Scale bars: A: 1mm; B and C: $0.5 \mathrm{~mm}$. This figure is in color in the electronic version.

Pharate Adult - This stage is the longest in the intrapuparial development, which corresponds to the stage where adult maturation occurs and the individuals have an adult aspect. This stage is divided into four sub-stages, delimited according to the pigmentation of the compound eyes (Fraenkel and Bhaskaran 1973; Pujol-Luz and Barros-Cordeiro 2012):

(1) Transparent eyes (observed at 120 to $245 \mathrm{~h}$ ): The division of the body into its main tagma (head, thorax and abdomen) is evident. The respiratory horn with red pigmentation is visible, and at this phase starts the development of the mouthparts. Additionally, the legs and wings are differentiated, but the wings do not present their membranous condition (Figure 4A). This is the longest substage lasting $125 \pm 2.15 \mathrm{~h}$ (Table 1).

(2) Yellow eyes (observed at 245 to $268 \mathrm{~h}$ ): The terminalia is visible, and the antennae, vibrissae, palpi and mouthparts are fully developed. Bristles without pigmentation emerge on the edges, and bristles and setae start developing on the legs. The wings develop their primary venation and setae are visible on their margins. The thoracic and abdominal sutures are well-defined in this stage (Figure $4 \mathrm{~B}$ ). This stage last 23 $\pm 0.89 \mathrm{~h}$ (Table 1 ).
A

$\mathrm{C}$

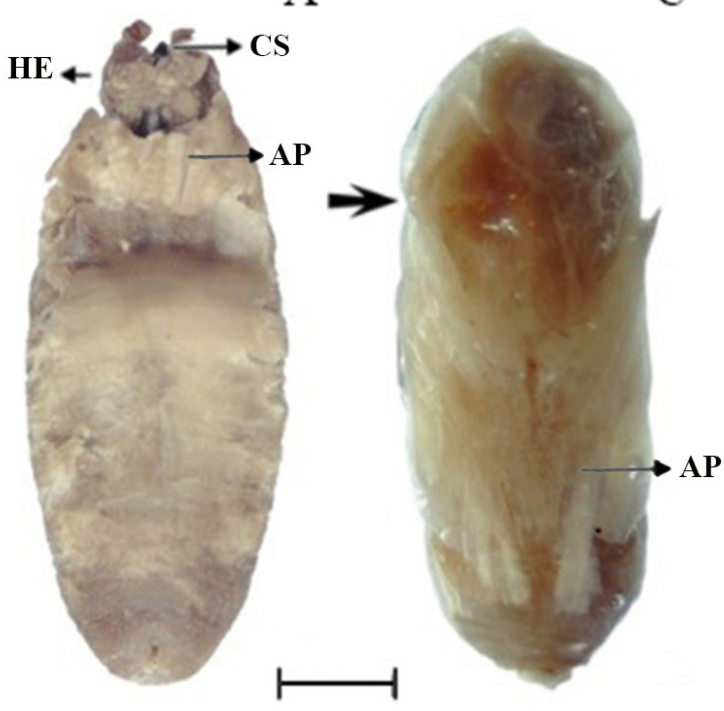

B

$\mathrm{D}$

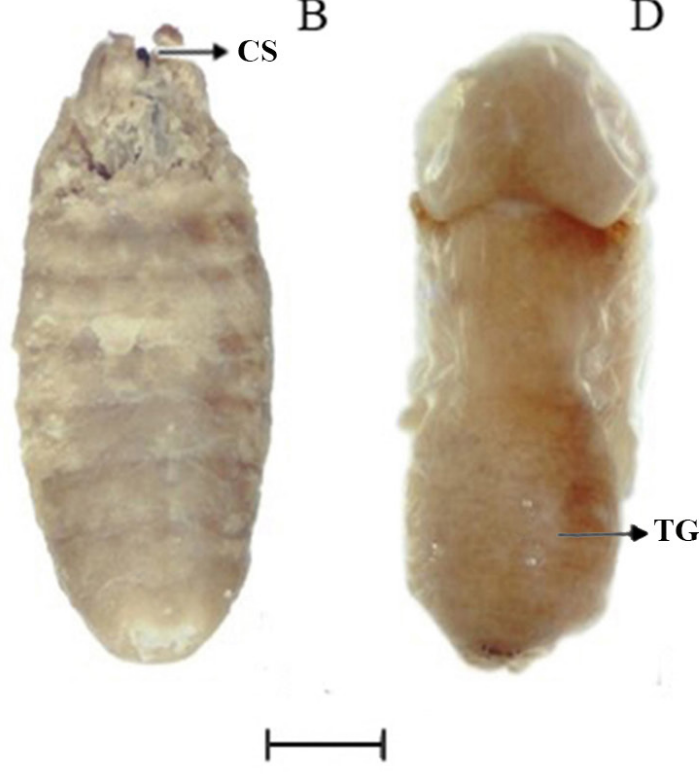

Figure 3. Morphological description of the intra-puparial development of Lucilia eximia. Cryptocephalic pupa with head and the thoracic appendages are still invaginated, in ventral view $\mathrm{A}$. The abdomen still with larval aspect, in dorsal view B. Phanerocephalic pupa with extroversion of the cephalic capsule (arrow) C. Differentiated thoracic segments and abdominal terguites D. CS: Cephalopharyngeal Skeleton, HE: Head, AP: Appendages, TG: Tergites. Cryptocephalic pupa: $5 \pm 0.53$ h. Phanerocephalic pupa: $92 \pm 1.94 \mathrm{~h}$. Scale bar: $1 \mathrm{~mm}$. This figure is in color in the electronic version.

(3) Pink eyes (observed at 268 to $282 \mathrm{~h}$ ): The development of the wings is completed and setae on the costal vein present black pigmentation. It is also possible to observe ocelli, spongy mouthparts, abdominals setae, head bristles, and well-developed claws (Figure 4C). It is the shortest sub-stage lasting $14 \pm 0.73 \mathrm{~h}$ (Table 1$)$. 


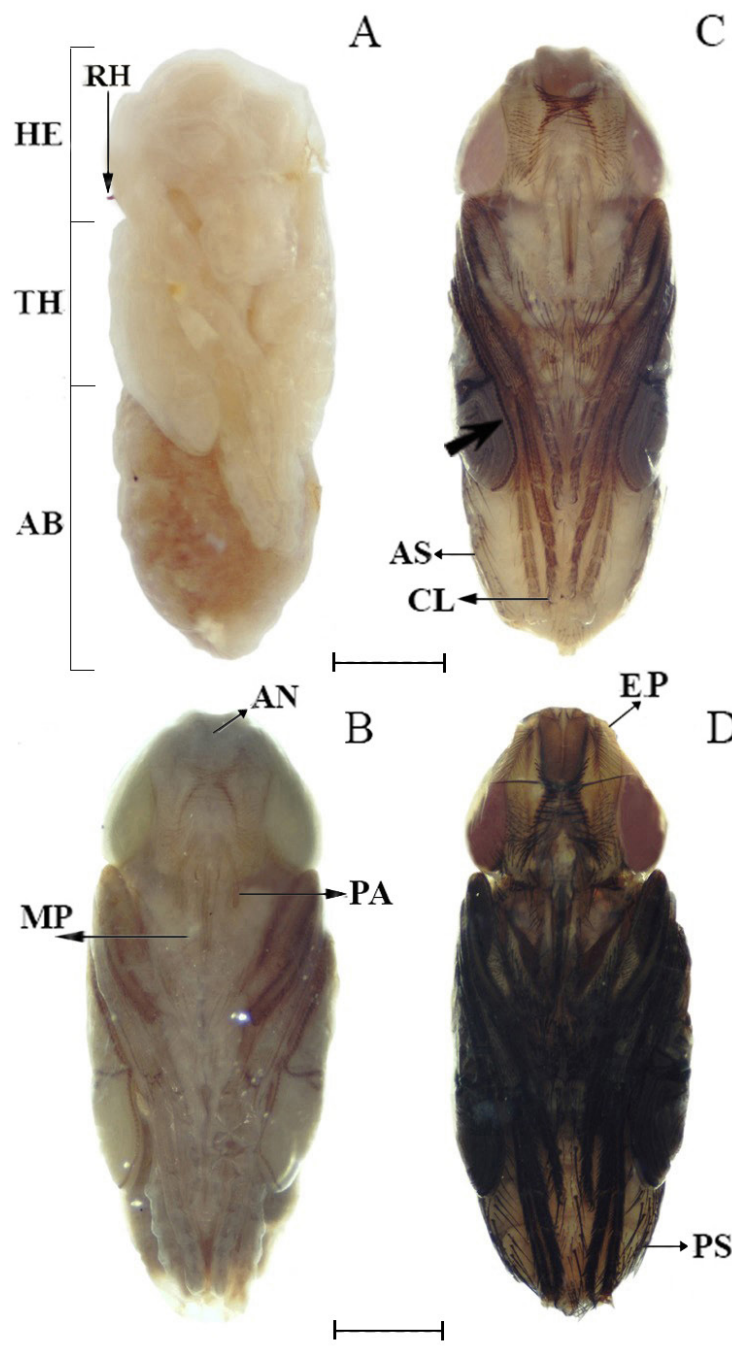

$\mathrm{E}$

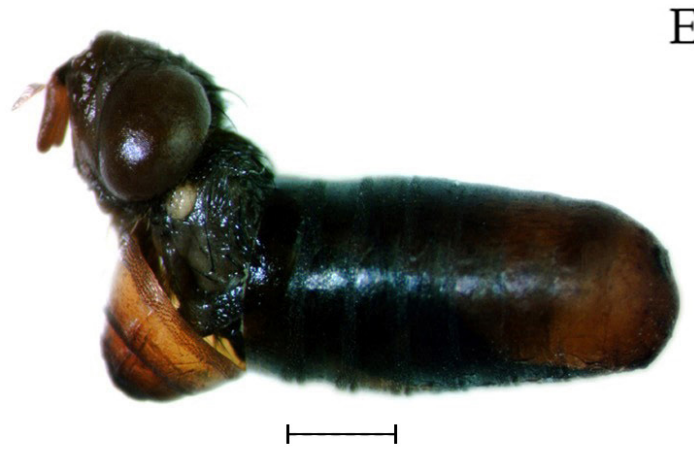

Figure 4. Morphological sequence of Pharate adult of Lucilia eximia, according to the pigmentation of the eyes. Transparent eyes A. Yellow eyes B. Pink eyes, with costal vein presenting black pigmentation (arrow) C. Red eyes D. Emergence of the adult E. HE: Head, TH: Thorax, AB: Abdomen, RH: Respiratory Horn, MP: Mouthparts, PA: Palpus, AN: Antennae, AS: Abdominal Setaes, CL: Claws, AP: Arista Plumose, EP: Pigmented Sternites. Scale bar: $1 \mathrm{~mm}$. Transparent eyes: $125 \pm 2.15 \mathrm{~h}$. Yellow eyes: $23 \pm 0.89 \mathrm{~h}$. Pink eyes: $14 \pm$ $0.73 \mathrm{~h}$. Red eyes: $20 \pm 0.60 \mathrm{~h}$. This figure is in color in the electronic version.
Table 1. Duration (in hours) of each stage of the intra-puparial developmental of the Lucilia eximia.

\begin{tabular}{|c|c|c|c|c|}
\hline Stage & Phases & $\begin{array}{l}\text { Beginning and } \\
\text { ending of the } \\
\text { phases (in hours) }\end{array}$ & $\begin{array}{c}\text { Time } \\
\text { Hours } \pm \text { SE }\end{array}$ & $\begin{array}{l}\text { Sample } \\
\text { size (n) }\end{array}$ \\
\hline \multirow[t]{4}{*}{ Pre-pupa } & Pupariation & 80 & $80 \pm 1.5$ & 260 \\
\hline & $\begin{array}{l}\text { Larva-pupa } \\
\text { apolysis }\end{array}$ & $0-23$ & $23 \pm 1.08$ & 80 \\
\hline & $\begin{array}{l}\text { Cryptocephalic } \\
\text { pupa }\end{array}$ & $23-28$ & $5 \pm 0.53$ & 20 \\
\hline & $\begin{array}{c}\text { Phanerocephalic } \\
\text { pupa }\end{array}$ & $28-120$ & $92 \pm 1.94$ & 300 \\
\hline \multirow[t]{5}{*}{ Pupa } & $\begin{array}{l}\text { Pharate adult } \\
\text { (compound eyes) }\end{array}$ & & & \\
\hline & Transparent eyes & $120-245$ & $125 \pm 2.15$ & 420 \\
\hline & Yellow eyes & $245-268$ & $23 \pm 0.89$ & 80 \\
\hline & Pink eyes & $268-282$ & $14 \pm 0.73$ & 50 \\
\hline & Red eyes & $282-302$ & $20 \pm 0.60$ & 50 \\
\hline Total time & & & 302 & 1000 \\
\hline
\end{tabular}

(4) Red eyes (observed at 282 to $302 \mathrm{~h}$ ): The whole body is fully developed. The main feature is beginning of the development of the ptilinum, the wings with a membranous condition, the black mouthparts, and the plumose arista and visible genitalia. Furthermore, the setae, tergites and sternites are strongly pigmented and well defined (Figure 4D). This stage lasts $20 \pm 0.60 \mathrm{~h}$ (Table 1 ).

\section{Imago and emergence}

After a period of $299 \pm 1.5$ hours, it as possible to observe the imago inside of the puparium, with the ptilinum totally formed and expanded. Emergence of the adults $(n=154)$ (Figure 4E) started after $302 \pm 3.81$ hours (Table 1).

\section{DISCUSSION}

Four stages of intra-puparial development were identified, which is in agreement with previous reports (Pujol-Luz and Barros-Cordeiro 2012; Barros-Cordeiro et al. 2014; CepedaPalacios and Scholl 2000).

The larva-pupa apolysis stage in L. eximia lasts $23 \pm 1.08$ $\mathrm{h}$, which corresponds to $7.62 \%$ of the total time of intra-pupal development. This contrasts with the report of Pujol-Luz and Barros-Cordeiro (2012), where this same stage in C. albiceps lasted just $3 \mathrm{~h}$ when reared at $26^{\circ} \mathrm{C}$, corresponding to $3 \%$ of the total development (Table 2).

Cryptocephalic pupa is the shortest stage $(5 \pm 0.53 \mathrm{~h})$ in $L$. eximia, which corresponds to $1.66 \%$ of the total intra-puparial development time. Previously, Pujol-Luz and Barros-Cordeiro (2012) reported $3 \mathrm{~h}$ for this stage in C. albiceps. 
Table 2. Duration (in hours) of each stage of the intra-puparial development and amount of time required up to the emergence of the adult (EAD) of eight species of Diptera. LPA larva-pupa apolysis, CPP Cryptocephalic pupa, PCP Phanerocephalic pupa, PHA Pharate adult. Adapted from Pujol-Luz and Barros-Cordeiro (2012).

\begin{tabular}{|c|c|c|c|c|c|c|c|c|}
\hline Family & Species & $\mathrm{T}^{\circ} \mathrm{C}$ & LPA & CCP & PCP & PHA & EAD & References \\
\hline Calliphoridae & Lucilia eximia & 26,8 & 23 & 5 & 92 & 182 & 302 & This study \\
\hline Calliphoridae & Calliphora erythrocephala & 24 & - & - & $24-25$ & - & 80 & Wolfe (1954) \\
\hline Muscidae & Musca domestica & 30 & 4 & $6-9$ & $16-18$ & 28 & 96 & $\begin{array}{c}\text { Frankel and } \\
\text { Bhaskaran (1973) }\end{array}$ \\
\hline Sarcophagidae & Sarcophaga bullata & 24 & 20 & $20-28$ & $46-48$ & $168-192$ & - & $\begin{array}{c}\text { Frankel and } \\
\text { Bhaskaran (1973) }\end{array}$ \\
\hline Oestridae & Cuterebra tenebrosa & 24 & $120-144$ & - & - & - & 1248 & Baird (1975) \\
\hline Oestridae & Dermatobia hominis & 24 & $72-120$ & - & $168-192$ & - & 720 & Lello et al. (1985) \\
\hline Oestridae & Oestrus ovis & 24 & 18 & 48 & 120 & 31 & 528 & $\begin{array}{l}\text { Cepeda-palacios and } \\
\text { Sholl (2000) }\end{array}$ \\
\hline Calliphoridae & Chrysomya albiceps & 26 & 3 & $3-6$ & $6-9$ & 81 & 90 & $\begin{array}{c}\text { Pujol-Luz and } \\
\text { Barros-Cordeiro (2012) }\end{array}$ \\
\hline
\end{tabular}

The phanerocephalic pupa stage lasted 92 hours, contrasting with the 3 hours reported by Pujol-Luz and Barros-Cordeiro (2012) for C. albiceps. At this stage the insect still has a pupal aspect, while Pujol-Luz and Barros-Cordeiro (2012) reported that, in C. albiceps, it is already possible to differentiate head, thorax and abdomen. At this stage in both species, it is possible to identify the prothoracic spiracles.

Pharate adult is the stage where $L$. eximia spends most of the intra-puparial development time $(182 \mathrm{~h})$. This data is in agreement with that observed by Pujol-Luz and Barros-Cordeiro (2012), who reported $81 \mathrm{~h}$ for C. albiceps. However, the starting point is different, being at $120 \mathrm{~h}$ for the current study, whereas it was at $9 \mathrm{~h}$ in the study by Pujol-Luz and Barros-Cordeiro (2012), which can probably be explained by the species belonging to different genera, beside the difference in relative humidity $(\mathrm{RH})$ during their development, as the temperatures used in both studies were similar $\left(25.46 \pm 1.21{ }^{\circ} \mathrm{C}, 93.31 \pm\right.$ $2.41 \% \mathrm{RH}$ and $26 \pm 1.0{ }^{\circ} \mathrm{C}, 60 \pm 10 \% \mathrm{RH}$, respectively).

During the pharate adult stage, we were able to identify four sub-stages according to the pigmentation of the eyes. Previously, the same number of sub-stages were reported for $C$. albiceps (Pujol-Luz and Barros-Cordeiro 2012), but the starting times and length of each sub-stage differed from the current study: 1) transparent eyes $39.74-81.13 \%$ of the total time (against $10-23 \%$ in C. albiceps); 2) yellow eyes $81.14-88.85 \%$ (22-66\% in C. albiceps); 3) pink eyes $88.93-93.57 \%$ (67-73\% in $C$. albiceps) and 4) red eyes $93.67-100 \%$ (74-100\% in C. albiceps). These discrepancies also may be due to the species belonging to different genera and to the different relative humidity conditions during their development.
Chrysomya albiceps is an Afrotropical species introduced in South America. It is considered the most abundant species in urban and rural zones (Barros-Souza et al. 2012). During its larval stage it is a facultative predator of eggs and larvae of other dipterans (Rosa et al. 2006). The features mentioned above can make $C$. albiceps responsible for the decrease of native species such as $L$. eximia, due to the interspecific competitions when these species are simultaneously present in a carcass. As a survival mechanism, L. eximia could have developed different colonization strategies, which would explain the different behavior when compared to C. albiceps.

Since the behavior and intra-puparial development time of L. eximia and C. albiceps are different, it is possible to state that when a person is trying to solve a cases involving death with long time of decomposition times, where the only entomological evidences are empty pupae and puparia of $L$. eximia and C. albiceps, the PMI estimation has to be calculated differently, as the PMI for each species is different.

\section{CONCLUSION}

One of the most common species of blow flies at the crime scenes in Colombia is L. eximia. Thus, this species has great importance and potential in determining the postmortem intervals. This study provided pupa development data of L. eximia for determining PMI. This species presented a relatively longer period of intra-puparial development than C. albiceps, which is very relevant for an accurate assessment of the postmortem interval. 


\section{ACKNOWLEDGMENTS}

The authors thank to the Colciencias Project 601-2009. To the entomology seed research of the Universidad de la Amazonia. To Universidad de Antioquia. To José Roberto Pujol-Luz (Universidade de Brasília), José Albertino Rafael and Gil Felipe Gonçalves Miranda (Instituto Nacional de Pesquisas da Amazônia) for reviewing the manuscript.

\section{REFERENCES}

Amendt, J; Krettek, R.; Zehner, R. 2004. Forensic entomology. Naturwissenschaften, 91: 51-65.

Archer, M.S.; Elgar, M.A. 2003. Effects of decomposition on carcass attendance in a guild of carrion-breeding flies, Medical Veterinary and Entomolgy, 17: 263-271.

Baird, C.R. 1972. Termination of pupal diapauses in Cuterebra tenebrosa (Diptera: Cuterebridae) with injections of ecdysterone. Journal of Medical Entomology, 9: 77-80.

Baird, C.R. 1975. Larval development of the rodent botfly, Cuterebra tenebrosa, in bushy-tailed wood rats and its relationship to pupal diapause. Canadian Journal of Zoology, 53: 1788-1798.

Barros-Cordeiro, K.B.; Báo, S.N.; Pujol-Luz, J.R. 2014. Intrapuparial development of the black soldier-fly, Hermetia illucens. Journal of Insect Science, 14: 1-10.

Barros-Souza, A.; Ferreira-Keppler, R.L.; Brito, D. 2012. Development period of forensic importance Calliphoridae (Diptera: Brachycera) In urban área under natural conditions in Manaus, Amazonas, Brazil. EntomoBrasilis, 5: 99-105

Bennett, G.F. 1962. On the biology of Cephenemya phobifera (Diptera: Oestridae), the pharyngeal bot of the white-tailed deer, Odocoileus virginianus. Canadian Journal of Zoology, 40: 1195-1210.

Calderón-arguedas, Ó.; Troyo, A.; Solano, M.E. 2005. Sucesión de larvas de muscoideos durante la degradación cadavérica en un bosque premontano húmedo tropical. Biomédica, 16: 79-85.

Cepeda-Palacios, R.; Scholl, P.J. 2000. Intra-puparial development in Oestrus ovis (Diptera: Oestridae). Journal of Medical Entomology, 37: 239-245.

Colwell, R.K. 2006. EstimateS: Statistical estimation of species richness and shared species from samples (Ver. 8). Avaliable at: http://purl. oclc.org/estimates (accessed 15 February).

Debry, R.W.; Timm, A.; Wong, E.S.; Stamper, T.; Cookman, C.; Dahlem, G.A. 2013. DNA-Based identification of forensically important Lucilia (Diptera: Calliphoridae) in the continental United States. Journal of Forensic Science, 58: 73-78.

Disney, R.H.L.; Manlove, J.D. 2005. First occurrences of the phorid, Megaselia abdita, in forensic cases in Britain. Journal of Medical and Veterinary Entomology, 19: 489-491.

Fraenkel, G.; Bhaskaran, G. 1973. Pupariation and pupation in cyclorraphous flies (Diptera): terminology and interpretation. Annals Entomolgical Society of America, 66: 418-422.

Garcés, P.A.; Bermudes, S.; Quintero, G. 2004. Determinación de la entomofauna asociada a carcasas de cerdos domésticos vestidos
(Sus scrofa), en el puerto de Vacamonte, Provincia de Panamá. Tecnociencia, 6: 59-74.

Lello, E.; Gregório, E.A.; Toledo, L.A. 1985. Desenvolvimento das gônadas de Dermatobia hominis (Diptera: Cuterebridae). Memórias do Instituto Oswaldo Cruz, 80: 159-170.

Ma, T.; Huang, J.; Wang, J.F. 2015. Study on the pupal morphogenesis of Chrysomya rufifacies (Maquart) (Diptera: Calliphoridae) for postmortem interval estimation. Forensic Science International, 253: 88-93.

Moura, O.M.; Carvalho, C.J.B.; Monteriro-Filho, E.L.A. 1997. A preliminary analysis of medico-legal importance in Curitiba, State of Paraná. Memórias do Instituto Oswaldo Cruz, 92: 269-274.

Pujol-Luz, J.R.; Da Costa, P.A.; Urarahy-Rodriguez, A.; Constantino, R. 2008. The black soldier-fly, Hermetia illucens (Diptera, Stratiomyidae), used to estimate the postmortem interval in a case in Amapá state, Brazil. Journal of Forensic Science, 53: 476-478.

Pujol-Luz, J.R.; Barros-Cordeiro, K.B. 2012. Intra-puparial development of the females of Chrysomya albiceps (Wiedemann) (Diptera, Calliphoridae). Revista Brasileira de Entomologia, 56: 269-27.

Ramos-Pastrana, Y.; Wolff, M. 2011. Entomofauna cadavérica asociada a cerdos expuestos al sol y sombra, en el piedemonte amazónico colombiano. Revista Momentos de Ciencia, 8: 45-54.

Ramos-Pastrana, Y.; Velasquez-Valencia, A.; Wolff, M. 2014. Preliminary study of insects associated to indoor body decay in Colombia. Revista Brasileira de Entomolgia, 58: 326-332.

Rocha, R.; Mello-Patiu, C.A.; Urarahy-Rodrigues, A. Guimaraes, C.; Carvalho, M.M. 2010. Temporal distribution of ten calyptrate dipteran species of medicolegal importance in Rio de Janeiro, Brazil. Memórias do Instituto Oswaldo Cruz, 105: 191-198.

Rosa, G.S.; De Carvalho, L.R. Dos Reis, S.F.; Godoy, A.C. 2006. The dinamics of intraguild predation in Chrysomya albiceps Wied. (Diptera: Calliphoridae): interactions between instar and species under different abundances of food. Neotropical Entomology, 35: 775-780.

Sanford, M.R.; Whitworth, T.L.; Phatak, D.R. 2014. Human wound colonization by Lucilia eximia and Chrysomya rufifacies (Diptera: Calliphoridae): myiasis, perimortem, or postmortem colonization ?. Journal of Medical Entomology, 51: 716-719.

Scholl, P.J.; Weintraub, J. 1988. Gonotrophic development in Hypoderma lineatum and H. bovis (Diptera: Oestridae), with notes on reproductive capacity. Annals of the Entomological Society of America, 81: 318-324.

Scholl, P.J. 1991. Gonotrophic development in the rodent bot fly Cuterebra fontinella (Diptera, Oestridae). Journal of Medical Entomology, 28: 474-476.

Ururahy-Rodrigues, A.; Rafael, J.A.; Pujol-Luz, J.R. 2013. Temporal distribution of blowflies of forensic importance (Diptera: Calliphoridae), in man-size domestic pig carcasses, in the forest reserve Adolpho Ducke, Manaus, Brazil. EntomoBrasilis, 6: 9-22.

Vargas, J; Wood, M. 2010. Calliphoridae (Blow Flies). In: Brown, B.V.; Borkent, A.; Cumming, J.M.; Wood, D.M.; Woodley, 
N.E.; Zumbado, M.A. (Ed.). Manual of central american Diptera. v.2. NCR, Research Press, Canada, Ottawa, Ontaro, p. 1297-1341.

Velásquez, Y.; Magaña, C.; Martínez-Sánchez, A.; Rojo, S. 2010. Diptera of forensic importance in the Iberian Peninsula: larval identification key. Journal of Medical and Veterinary Entomology, 24: 293-308

Whitworth, T. 2014. A revisión of the Neotropical species of Lucilia Robineau-Desvoidy (Diptera: Calliphoridae). Zootaxa, 3810 $: 1-76$.

Wolfe, L.S. 1954. Stuies of the development of the imaginal cuticule of Calliphora erythrocephala. The Quartely Journal of Microscopical Science, 95: 67-78.

Received: 16/03/2016

Accepted: 23/06/2016 